\title{
Editorials
}

\section{Should UK primary care be an early adopter of genomic medicine?}

\section{INTRODUCTION}

Increasingly, genomic data are being used for the diagnosis and treatment of disease, and in due course could be used for the prevention of disease. ${ }^{1}$ Following multiple endorsements of genomic medicine in 2018, UK Secretary of State for Health and Social Care, Matt Hancock, announced in January 2019 the development of a directto-consumer service for whole-genome sequencing, with provision for 'customers' to donate their data for research purposes. ${ }^{2}$ We present a dissensus - arguments why UK primary care should, and why it should not, be an early adopter of this technology, in order to understand its ethical aspects.

\section{UK PRIMARY CARE SHOULD BE AN} EARLY ADOPTER OF GENOMIC MEDICINE

Genomic medicine is already with us in the NHS. The 100000 Genome Project (https://www.genomicsengland.co.uk/) has generated regional genomic medical centres, which will help in determining the clinical utility of gene variants. We already have genomic databases that aim to link genotype with phenotype.

Anyone in the UK, including patients and their families, can pay for an over-thecounter genetic test that provides information on long-term conditions, such as asthma or hypertension, as well as information about personal traits. There is a duty to respond to their needs for knowledge, and consider targeted treatments and avoidance of potentially harmful treatments that are unlikely to work. We have to understand the opportunities and limitations presented by patients turning up with genomic information to discuss, and GPs will identify learning needs as a result of exposure to genomic conversations with patients.

By definition, the genomic patient has acquired a disorder through no fault of their own but by reason of being born. Thus the early use of genomic medicine tackles the inequality of opportunity that is 'bred in the bone'. Wider determinants of health notwithstanding, we must not ignore the potential for individual and societal benefits of new medical approaches. Monogenic conditions, such as Huntington's disease, can be life-threatening, as can polygenic conditions, such as ischaemic heart disease. It is in the polygenic field - the realm of genomics - that great promise for patient benefit lies.

\section{"Genetic testing should never be taken lightly - we are talking about sensitive patient data, with potentially serious medical and ethical implications}

There is an intuitive argument that (when they are available) all available technologies that could be deployed to patient benefit ought to be lethics should not be synonymous with hindrance), and that not being an early adopter means not being in control of the emerging technology and perhaps even paying more for it as a result.

\section{UK PRIMARY CARE SHOULD NOT BE AN EARLY ADOPTER OF GENOMIC MEDICINE}

However, the evidence base for genomic medicine is incomplete, the technology still promissory, and the underpinning ethical assumptions insufficiently scrutinised. ${ }^{3}$ This does not argue for or against genomic medicine per se, but raises concerns about its premature adoption.

Genomic medicine is a term used to describe a new paradigm for health care, building on the Human Genome Project, by using molecular profiling to identify multifactorial health risks and to develop pharmacogenomic drugs, rather than the supposedly dominant one size fits all' model in prescribing. Emphasis on individuality is evident in the widespread use of the term 'personalised' medicine. More recently the terms 'stratified' and 'precision' medicine have come into favour, 4,5 but lack the powerful appeal of personalised medicine, with its promises of greater patient empowerment. ${ }^{6}$

If the science behind personalised or genomic medicine is as far advanced as its proponents claim, that would not satisfy ethical qualms about whether it is right or feasible to make clinical decisions on the basis of a patient's genetic profile. ${ }^{7.8}$ The decision to offer or withdraw treatment based on the probability (not certainty) that it will work has little to do with respect for autonomy. It is frequently argued that genomic personalised medicine will be both more efficient and more cost-effective, because resources will not be wasted on patients whose genotype makes them unlikely to respond to a targeted drug. But this ignores the serious ethical question of whether or not it is fair to deny treatment to those patients if they request or require it lsome chance of benefit being better than none). Evidence of a likely benefit is already a rationing tool - why would a genetic profile not be used in this way?

There is a concern that genomic data will lead to genetic discrimination. In the UK at least, GPs have a role as stewards of patient data. For example, GPs are often asked for medical reports to help decide insurance premiums. The UK insurance industry has a self-imposed moratorium, recently extended until 2019, that states they will not ask policy holders to have a genetic test, or for the results of a genetic test, for policies valued at less than $5500 \mathrm{k}$ for life-insurance purposes land less than $€ 300 \mathrm{k}$ for other purposes). Above these limits, only tests specially approved can be used. However, family history of disease continues to be used to load or refuse premiums. ' We wonder whether such a moratorium would be maintained were genomic information to be as much a part of everyday general practice as a 'family history'. Function creep, where technology purchased for a good purpose is used for less laudable aims, is also a concern. We have seen this in the use of confidential patient data to detect failed asylum seekers and there is already discussion that the genome might be used for forensic purposes. ${ }^{10}$ 
Target populations for pharmacogenomic drugs will necessarily be smaller than the population as a whole.11,12 However, drugs that target a narrower segment of the patient population are often more expensive: one such drug for cystic fibrosis in the US, for example, costs $\$ 300000$ a year. ${ }^{3}$ Indeed, primary health care already has more tools, and indeed problematic issues, than it knows what to do with. Caution is needed when commissioning promising but costly technologies before their benefit is proven, especially if this would mean having to decommission something else.

\section{DISCUSSION}

Our consensus, if there is one, is capably phrased by RCGP Chair Helen StokesLampard: Genetic testing should never be taken lightly - we are talking about sensitive patient data, with potentially serious medical and ethical implications for the patient and all their genetic relatives. People really need to consider these implications carefully before they decide to take a genetic test. ${ }^{13}$

Points in favour of early adoption focus on the technology already being available. Engagement with it would therefore shape it as a force for good. Potentially reducing suffering and maximising resources are possible positive features of this engagement. Points in opposition highlight potential misuse of the technology, but also highlighted the idea that it is still promising rather than delivering, and that in times of financial austerity represents an unaffordable technology with unaffordable care-implications.

We suggest a need for better understanding of genomic medicine, especially in light of genomic testing being available as a direct-to-consumer service and in 2019 its explicit endorsement by the
Secretary of State for Health. We commend Health Education England educational resources ${ }^{14}$ as well as the recent Lucassen and Farsides paper on ethical issues inherent in genetics and genomics for GP trainees. ${ }^{9}$ Any rational debate must be founded on good information. We welcome further discussion, especially on Twitter using the \#RCGPAC, or in direct responses to the BJGP.

\section{Donna Dickenson,}

Emeritus Professor of Medical Ethics and Humanities, University of London, London.

\section{Imran Rafi,}

GP, Banstead; Senior Lecturer, St George's, University of London, London.

\section{John Spicer,}

GP, Croydon; Head of Primary Care Education, Health Education England [South London], London.

\section{Andrew Papanikitas,}

Senior Clinical Researcher in General Practice, Nuffield Department of Primary Care Health Sciences, University of Oxford, Oxford.

\section{Provenance}

Freely submitted; externally peer reviewed.

\section{Competing interests}

Imran Rafi is an RCGP Clinical Champion for Genomics and AoMRC Champion for Genomics. All other authors have declared no competing interests.

\section{Acknowledgements}

This editorial began as a debate at the 2017 RCGP Annual Conference, led by members of the RCGP Committee on Medical Ethics (COME). The views expressed are the authors' own and not those of COME or of the RCGP. We thank Professor Simon Gregory who chaired the debate, and the Conference Management Committee who included the debate in the main programme. We also thank the roughly 100 participants at the debate for broadening our horizons on this topic.

DOI: https://doi.org/10.3399/bjgp19X704201

\section{ADDRESS FOR CORRESPONDENCE}

\section{Andrew Papanikitas}

Nuffield Department of Primary Care Health Sciences, University of Oxford, Radcliffe Observatory Quarter, Woodstock Road, Oxford OX2 6GG, UK.

Email: andrew.papanikitas@phc.ox.ac.uk

\section{REFERENCES}

1. Rafi I, Spicer J. Genethics and genomics in the community. In: Papanikitas A, Spicer J, eds. Handbook of primary care ethics. Abingdon: CRC Press, 2017: 169-178.

2. Rawlinson K. NHS to sell DNA tests to healthy people in push to find new treatments. Guardian 2019; 26 Jan: https://umw. theguardian.com/society/2019/jan/26/nhs-tosell-dna-tests-to-healthy-people-in-push-tofind-new-treatments (accessed 11 Jun 2019).

3. Joyner MJ, Paneth N. Seven questions for personalized medicine. JAMA 2015; 314(10): 999-1000.

4. Precision Medicine Initiative. Working Group. Working Group report to the Advisory Committee to the Director, NIH. The Precision Medicine Initiative Cohort Program - building a research foundation for 21st century medicine. PMI, 2015

5. Sabatello M, Appelbaum PS. The precision medicine nation. Hastings Cent Rep 2017; 47(4): 19-29. DOI: 10.1002/hast.736.

6. Juengst E, McGowan M, Fishman JR, Setterstein RA. From 'personalized' to 'precision' medicine: the ethical and social implications of rhetorical reform in genomic medicine. Hastings Cent Rep 2017; 46(5): 21-33.

7. Dickenson D. Ethical qualms about genetic prognosis. Canadian Med Ass J 2013; 188(6): 453-454

8. Dickenson D. Me medicine vs, we medicine: reclaiming biotechnology for the common good New York, NY: Columbia University Press, 2016.

9. Lucassen A, Farsides B. Ethical issues in genetic medicine. InnovAiT 2017; 10(8): 481488

10. Samuel G, Painsack B. Forensic DNA phenotyping in Europe: views 'on the ground' from those who have a professional stake in the technology. New Genet Soc 2019; https://www. tandfonline.com/doi/full/10.1080/14636778.2018 .1549984 laccessed 14 Jun 2019).

11. Chiang A, Milton RP. Personalized medicine in oncology: next generation. Nat Rev Drug Discov 2011; 10(12): 895-896.

12. Collins FS. The language of life: DNA and the revolution in personalized medicine. New York, NY: Harper Perennial, 2011.

13. Stokes-Lampard H. Genetic testing should never be taken lightly. 2019. https://www.rcgp. org.uk/about-us/news/2019/march/genetictesting-should-never-be-taken-lightly-saysrcgp.aspx (accessed 13 Jun 2019).

14. Genomics Education Programme. Health Education England. https://nww. genomicseducation.hee.nhs.uk/ laccessed 12 Jun 2019). 